Arq. Bras. Med. Vet. Zootec., v.65, n.3, p.627-630, 2013

\title{
Bilateral extraluminal ectopic ureters in a Maine Coon cat
}

[Ureter ectópico extraluminal bilateral em um felino da raça Maine Coon]

\author{
L.Z. Crivellenti ${ }^{1}$, A.E.W.B. Meirelles ${ }^{1}$, M.C.H. Rondelli ${ }^{1}$, S. Borin-Crivellenti ${ }^{1}$, P.C. Moraes ${ }^{1}$, \\ A.L. Andrade ${ }^{1,2}$, M.B. Carvalho ${ }^{1}$ \\ ${ }^{1}$ Universidade Estadual Paulista (Unesp) - Jaboticabal, SP \\ ${ }^{2}$ Universidade Estadual Paulista (Unesp) - Araçatuba, SP
}

\begin{abstract}
Ectopic ureters are rarely observed in cats. Therefore, for a better chance of success in the corrective surgical procedure and survival of the patient, diagnosis should be confirmed early. This report illustrates the occurrence of bilateral ectopic ureters in a seven month old Maine Coon cat and describes the medical and surgical management adopted for correction of the abnormality.
\end{abstract}

Keywords: feline, excretory urography, ureteroneocystostomy, surgery complication

\section{RESUMO}

A ectopia dos ureteres é raramente observada em gatos. Assim, para aumentar as chances de sucesso do procedimento cirúrgico corretivo e promover a sobrevivência, o diagnóstico deve ser firmado precocemente. $\mathrm{O}$ relato em tela ilustra a ocorrência de ureter ectópico bilateral em uma gata Maine Coon, de sete meses, e descrevem-se as manobras médico-cirúrgicas adotadas na correção dessa anormalidade.

Palavras-chave: felino, urografia excretora, ureteroneocistostomia, complicação cirúrgica

\section{INTRODUCTION}

Ectopic ureter is a rare condition in cats and, differently from dogs, no breed predisposition is recognized (Kuzma and Holmberg, 1988). It consists of a congenital anomaly due to an alteration in the origin of the terminal segment of the mesonephric duct of one or both ureters, in which the ureteral orifice does not insert within the vesical trigone (Mcloughlin and Chew, 2000).

The extraluminal form occurs when the ureters completely deviate from the bladder, changing their anatomical path and opening in the urethra or vagina (Hoelzler and Lidbetter, 2004; Fossum, 2005). This abnormality is associated with continuous urinary incontincence (Kuzma and Holmberg, 1988; Mcloughlin and Chew, 2000), frequently accompanied by bacterial infection and signs of cistitis (Fossum, 2005), hematuria
(Burbidge et al., 1989) and hydronephrosis (Ghantous and Crawford, 2006).

Diagnosis can be established by an association of the clinical history and abdominal radiography, excretory urography, retrograde urethrocystography, pneumocystography, abdominal ultrasound (Burbidge et al., 1989; Tattersall and Welsh, 2006), computed tomography and cystoscopy (Hoelzler and Lidbetter, 2004).

Complementary laboratory exams do not reveal alterations unless hydronephrosis promotes functional loss of renal parenchyma or when ascending renal infections occur (Hoelzler and Lidbetter, 2004 ).

The treatment for ectopic ureter is based, in most cases, in ureteroneocystostomy (Kuzma and Holmberg, 1988; Fossum, 2005).

Recebido em 30 de agosto de 2012

Aceito em 2 de fevereiro de 2013

E-mail: crivellenti_lz@yahoo.com.br 


\section{Crivellenti et al.}

\section{CASE REPORT}

A $3.4 \mathrm{~kg}$ seven month old Maine Coon cat was admitted by the Nephrology and Urology Section of the Veterinary Hospital at UNESP, Jaboticabal, SP, Brazil, with a history of urinary incontinence since birth and exhibiting hyporexia, vomiting, polyuria, polydipsia and weight loss for 30 days.

General physical examination showed mild dehydration and marked enlargement of both kidneys on abdominal palpation. Laboratory findings revealed mild normocytic normochromic anemia, azotemia (creatinine $2.6 \mathrm{mg} / \mathrm{dL}$ and urea $167 \mathrm{mg} / \mathrm{dL}$ ), hyperphosphatemia $(6.5 \mathrm{mg} / \mathrm{dL})$, hyponatremia $(133 \mathrm{mmol} / \mathrm{L})$ and hypoalbuminemia $(2.1 \mathrm{mg} / \mathrm{dL})$. Urinalysis revealed decreased urinary density (1.010), $\mathrm{pH}$ (6.5), marked leukocyturia and bacteriuria, moderate number of red blood cells and transitional epithelial cells. Urine culture confirmed the presence of Escherichia coli and sodium ampicillin $(22 \mathrm{mg} / \mathrm{kg}$ orally, every 12 hours) and fluid therapy $(100 \mathrm{~mL} /$ day of Ringer's sodium lactate, subcutaneously) were prescribed, and most of the parameters improved better before excretory urography and surgery.

Ultrasound examination confirmed renomegaly $($ right kidney $=6 \times 3.8 \mathrm{~cm}$, left kidney $=$ 4.08x2.45), hydronephrosis with accompanying dilated ureters and atrophy of the renal tissue, bilaterally.

Excretory urography, performed after the treatment mentioned above, confirmed bilateral ectopic ureters with an apparent reduction in the function of the right kidney (Figure 1).

Exploratory laparotomy was performed and after confirmation of right hydronephrosis with loss of the renal parenchyma associated to possible contamination based on urinalysis findings, right nephrectomy was performed.

The remaining ureter was ligated and transected at the insertion site on the urethra, preserving its length. The technique chosen in this case was ureteroneocystostomy with an intramural tunnel (3:1 tunnel length to uretereral orifice diameter). For implantation in the bladder, the ventral mucosa of the bladder was incised creating a short, oblique submucosal tunnel in the bladder wall "tunnelization". A $2 \mathrm{~mm}$ longitudinal incision was performed in the ureter end and it was sutured to the bladder mucosa with a 5-0 polyglecaprone absorbable suture (Monocryl ${ }^{\circledR}$ ) (Figure 2).

Six hours after the end of the surgery, the animal exhibited anuria and cardiopulmonary arrest, with progression to death

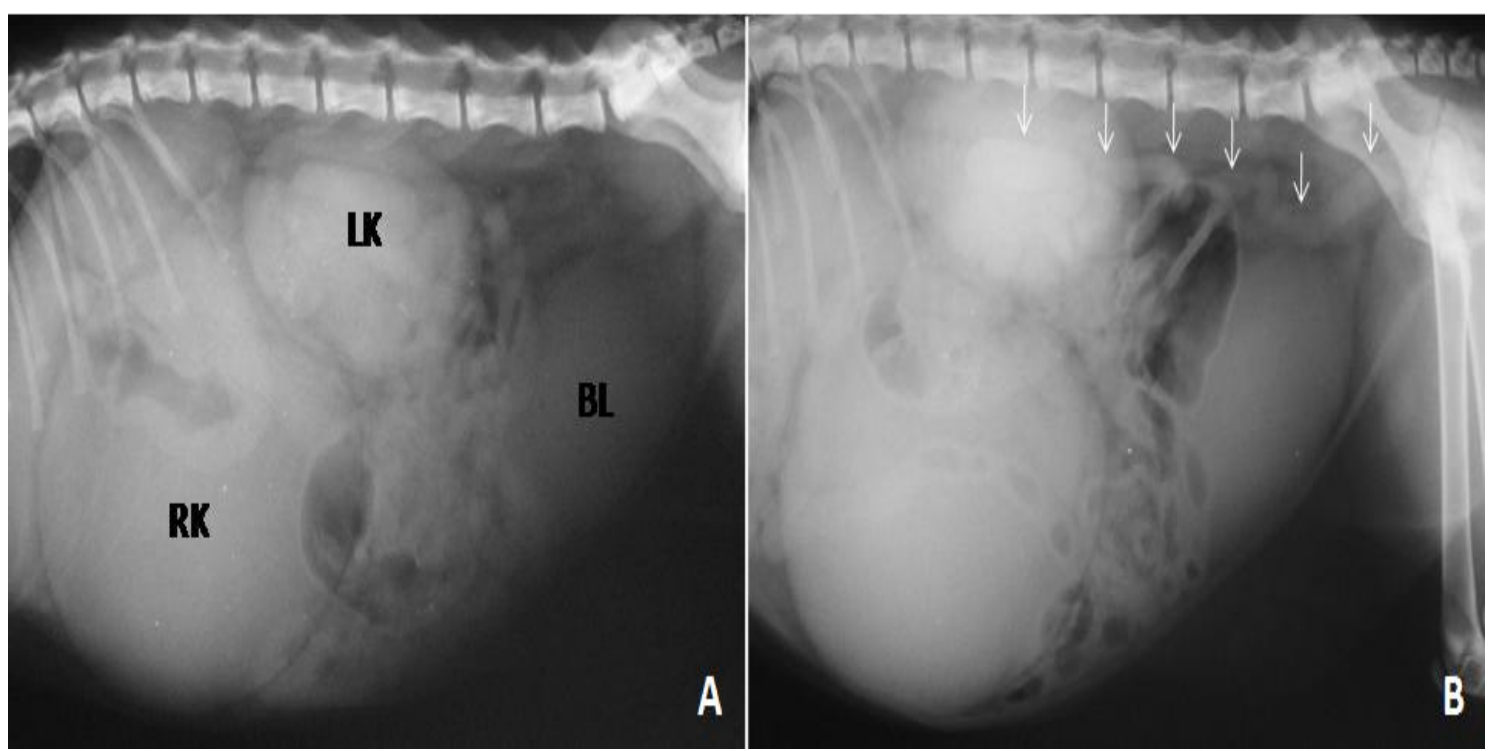

Figure 1. Excretory urography. Note (A) identification of structures and bilateral renomegaly and, (B) arrows showing implantation of ureters in the urethra (RK: righ kidney, LK: left kidney, BL: bladder) 


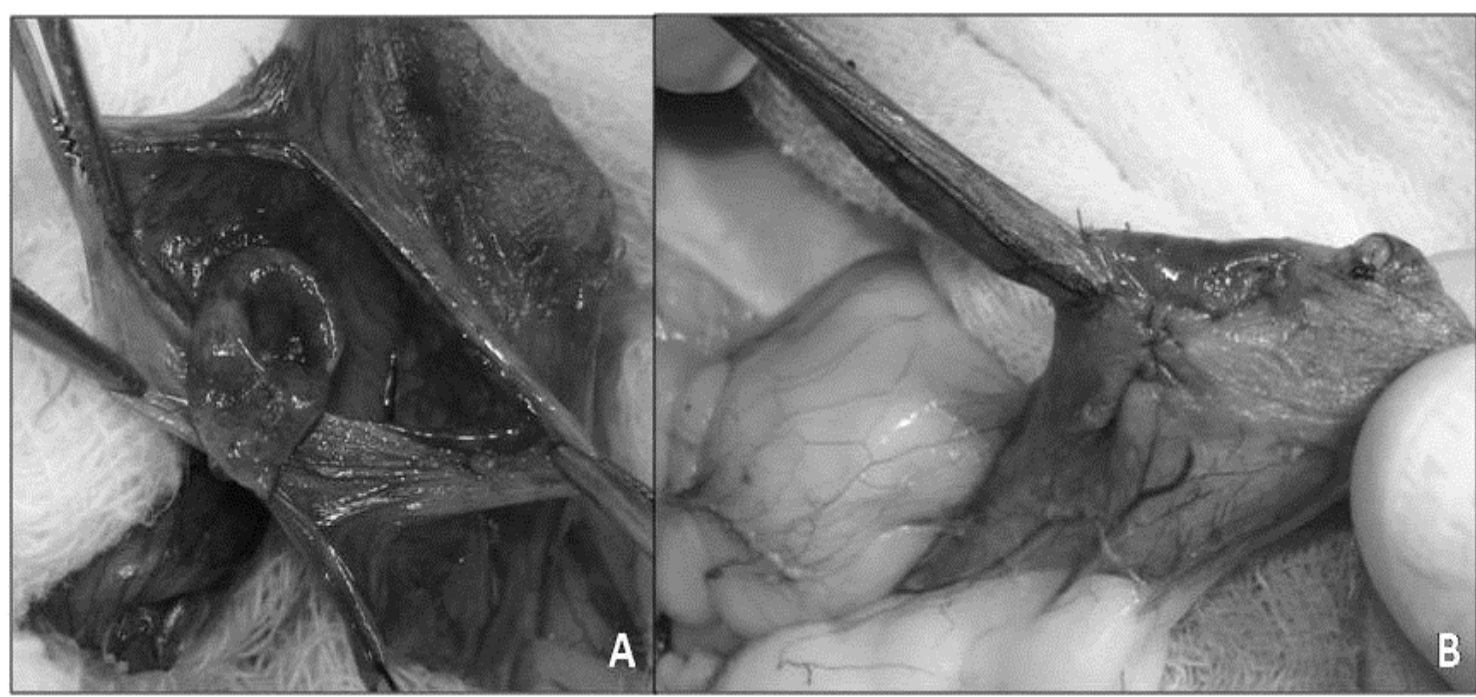

Figure 2. Note in A, the beginning of implantation of the ureter into the bladder. In B, completed ureteroneocystostomy and cystorrhaphy.

\section{RESULTS AND DISCUSSION}

Only one case of ureteral constriction on the insertion of the bladder has been reported in literature (Zotti and Poser, 2004). To our knowledge, there are no reports of ectopic ureter in this breed (Maine Coon), which was the motivation for reporting this case. Similarly to the majority of cases with this disease (Fossum, 2005, Kuzma and Holmberg, 1988), this animal exhibited hydronephrosis caused by the ectopic ureteral insertion (Zotti and Poser, 2004) and signs of renal failure due to loss of functional parenchyma, resulting from late diagnosis.

Before the anesthetic and surgical procedures were carried out, there was an attempt to correct the hydro-electrolytic and acid-base imbalances as well as concomitant urinary infections with fluid therapy and antibiotics (Fossum, 2005; Crivellenti, 2012).

The ultrasound examination revealed important bilateral hydronephrosis and hydroureter with possible urethral insertion, which was later confirmed by excretory urography and surgery. Decreased right renal function was also demonstrated, which was determinant for the nephrectomy decision.

Furthermore, resection of the right kidney and ureter were performed since there was purulent material associated to bacterial infection even after antibiotic therapy was administered. In the same procedure, ureteroneocystostomy of the contralateral ureter (left) was performed due to rapid prograssion of hydronephrosis. The intramural tunnel technique was used with the aid of a magnifying glass (Burbidge et al., 1989; Fossum, 2005) in an attempt to restore the normal ureteral flow. Absorbable suture was chosen with the objective of minimizing risks of calculi formation close to the suture, as well as infection of the bladder mucosa (Fossum, 2005).

The most frequent complication of ureterovesical anastomosis is partial obstruction of urine flow, with consequent hydroureter and hydronephrosis. However, partial or total obstruction can happen immediately after surgery due to edema and inflammation (Kuzma and Holmberg, 1988), which is an important factor for patients with only one kidney. The use of prednisone is recommended previous to the procedure (Kuzma and Holmberg, 1988) or even the use of a stent (Burbidge et al., 1989). These were not employed in this case due to the presence of pyelonephritis, and only antibiotics were administered. It is probable that death occurred due to partial obstruction of flow, which was already compromised because of the loss of the renal function. This can also be justified by the occurrence of azotemia, also reported by Mehl et al. 2005 (Mehl et al., 2005), which evaluated cats with ectopic ureter and no renal dysfunction. These animals were subjected to unilateral nephrectomy followed by ureteroneocystostomy of the contralateral ureter. All of them developed 


\section{Crivellenti et al.}

azotemia after surgery, which was attributed to postsurgical obstruction, and death was reported in $20 \%$ of the animals. The use of mannitol to try to stimulate diuresis and maintain the flow has been described; however, with no encouraging results (Mehl et al., 2005).

The postoperative care should be intense, especially in cases of correction of bilateral ectopia performed in a single procedure (Fossum, 2005; Crivellenti, 2012). Moreover, the knowledge of new postoperative therapies is important to minimize post-renal azotemia and immediate complications, especially faced with the impossibility of using hemodialysis due to the patient's weight.

\section{REFERENCES}

BURBIDGE, H.M.; JONES, B.R.; MORA, M.T. Ectopic ureter in a male cat. N. Z. Vet. J., v.37, p.123-125, 1989.

CRIVELLENTI, L.Z. Nefrologia e Urologia. In: CRIVELLENTI, L.Z.; BORIN-CRIVELLENTI, $\mathrm{S}$. Casos de rotina em medicina veterinária de pequenos animais. 1.ed. São Paulo: MedVet LTDA, 2012. p.255-304.

FOSSUM, T.W. Cirurgia dos rins e ureteres. In: FOSSUM, T.W. Cirurgia de pequenos animais. 2.ed. São Paulo: Roca LTDA, 2005. p.551-571.
GHANTOUS, S.N.; CRAWFORD, J. Double ureters with ureteral ectopia in domestic shorthair cat. J. Am. Anim. Hosp. Assoc., v.42, p.462-466, 2006.

HOELZLER, M.G.; LIDBETTER, D.A. Surgical management of urinary incontinence. Vet. Clin. North Am. Small Anim. Pract., v.34, p.10571073, 2004.

KUZMA, A.B.; HOLMBERG, D.L. Ectopic ureter in a cat. Can. Vet. J., v.28, p.59-61, 1988.

MEHL, M.L.; KYLES, A.E.; POLLARD, R. et al. Comparison of 3 techniques for ureteroneocystostomy in cats. Vet. Surg., v.34, p.114-119, 2005.

MCLOUGHLIN, M.A.; CHEW, D.J. Diagnosis and Surgical Management of Ectopic Ureters. Clin. Tech. Small Anim. Pract., v.15, p.17-24, 2000.

TATTERSALL, J.A.; WELSH, E. Ectopic ureterocele in a male dog: a case report and review of surgical management. J. Am. Anim. Hosp. Assoc., v.42, p.395-400, 2006.

ZOTTI, A.; POSER, H.; CHIAVEGATO, D. Asymptomatic Double ureteral stricture in a 8-month-old Maine Coon cat: an imaging-based case report. J. Feline Med. Surg., v.6, p.371-375, 2004. 